\title{
The Effectiveness of Professional Training Programs in Developing the Digital Skills of Arabic Language Teachers from the Perspective of Principals and Academic Supervisors
}

\author{
DR.REEM ABDELKAREEM AWWAD ALOMOUSH \\ Part-time lecturer-The world Islamic Sciences and Education University, Amman, Jordan
}

\begin{abstract}
The researcher of the present study aimed to explore the effectiveness of professional training programs in developing the digital skills of Arabic language teachers in the public schools in Zarqa. The sample consists from 108 female and male principals and academic supervisors. She used a questionnaire that consists from 41 items. This questionnaire sheds a light on 4 digital skills-related areas. It was found that the digital skill level of Arabic language teachers in the four areas jointly is moderate. It was found that there are differences between the respondents' attitudes towards the effectiveness of the aforementioned program in developing (intermediate and advanced skills).
\end{abstract}

Keywords:Digital skills, professional training, Arabic language teachers.

DOI: $10.7176 / \mathrm{JEP} / 11-36-07$

Publication date: December $31^{\text {st }} 2020$

\section{Introduction}

Scholars and teachers have a great significance in society, because they contribute to developing their homeland and make great sacrifices. That is because teachers play a significant role in developing societies. For instance, teachers play a major role in providing the members of the society with knowledge and experiences. They also play a major role in promoting specific attitudes among the members of the society and instilling values within them. They play a significant role in implementing educational policies and improving the quality of education and the outcomes of educational institutions. Due to the significant role of teachers, much attention has been provided to teacher development and training.

During the end of the 20th century, the world experienced a digital revolution. This revolution created a digital world. It enabled professionals to design virtual learning environment. Due to such revolution, it become necessary to make changes to the elements of the educational systems. Therefore, all governments have been exerting efforts to improve their educational systems. Such efforts include: developing teachers. Through exerting such effort, societies shall develop in all aspects (Al-Awadi, 2013).

To keep up with the latest digital development, decision makers must make changes to the educational system in accordance with modern educational standards. They must employ modern technologies in educational institutions. Such employment shall contribute to making major developments to the educational systems. It shall contribute to meeting the intended educational goals and providing teachers with the required digital skills (AlMooshi, 2016).

Language is considered a significant method in order for people to communicate and think effectively. It enables one to carrying out cognitive activities. Many technologies were invented to simulate humans' cognitive functions (Abdellah, 2008). Therefore, many Arab countries -e.g. Jordan- took measures to improve the educational system and the quality of education. In this regard, more attention must be provided to the Arabic language education. That is because there are several Arab and global challenges that hinder the delivery of high quality Arabic language education. Due to facing such challenges, more attention must be provided for the professional development of Arabic language teachers. The skills of those teachers must be developed, to enable them to keep up with the latest digital development. That shall improve the performance of those teachers and improve the outcomes of educational institutions.

There various methods to develop and train teachers in general and Arabic language teachers in particular. Such methods include: the provision of professional training programs. The latter programs improve the quality of Arabic language education. They are needed due the increase of the number of teachers and the increase of their duties. They enable teachers to serve as role models for their students and interact effectively with students in classroom. They develop the teachers' researching skills and promote creativity and innovation among teachers. They improve the outcomes of educational institutions (Al-Harbi, 2016).

The development of teachers in general and Arabic language teachers in particular is a significant issue. Thus, many studies worldwide are conducted about this issue. That's because such development affects the teachers' performance and provide them with skills, knowledge and experiences. It's because such development enables teachers to teach in accordance with educational, psychological and scientific standards (Al-Harahsheh, 2010).

The teacher professional training programs are needed due to occurrence of rapid changes. Such changes 
include: the changes in IT, science, communication methods and the demands of the labor market. Due to such changes, the workplace environment has changes. Thus, job seekers must have excellent digital skills that enable them to keep up with the changes in the workplace environment. Having excellent digital skills shall enable job seekers to find opportunities and seize them (Khalil, 2011).

The teacher professional training programs contribute to developing teachers' skills and providing them with knowledge. They improve the teachers' capabilities to do their tasks efficiently. Trainers in such programs must employ training methods that fit with the training needs of teachers (Corcoran, 1995). The professional training programs of in-service teachers provide teachers with the latest knowledge and updates related to the teaching profession. They contribute to making reforms to educational systems and letting teachers handle their responsibilities efficiently. They are considered an essential element of any attempt that aims at making reforms to an educational system (GusKey, 2000).

According to Davies (1991), teachers who receive a little amount of training usually carry out limited types of school activities. They also rely on the content of the curricula. If the teachers' professional development programs are well-planned, there shall be a great number of excellent teachers who practice their profession well. Davies (1991) recommends setting the standards that must be met by the successful teacher. Such standards must be read by novice teachers. Teachers must be informed about such standards (Davies, 1991).

According to Ali (2011), training teachers plays a major role in providing the members of the society with competencies. It shall contribute to the development of society and meeting the society' needs. It shall develop the teachers' technical skills which become are during the digital age. During the digital age, information are saved in a digital manner instead of using paper-based files. It can accessed locally and internationally (Ali, 2011).

The most important in-service teacher professional training programs are the ones that aim at developing the in-service teachers' digital skills. Such programs enable teachers to keep up with the technological developments and information explosion in all the fields. Teachers must keep developing themselves professionally. That shall make them creative and enable them to use technology efficiently. However, it's challenging for teachers to do that (Al-Mallah, 2019).

Based on the aforementioned, making reforms to the educational system is highly needed. That is attributed to the challenges derived from the digital revolution. Due to facing such challenges, new methods must be used for developing the teachers' skills, enabling them to use various types of ICTs and improving their performance. New methods must be used for enabling teachers to construct knowledge (Al Soroor, 2018).

\section{Statement of the Problem:}

The researcher aimed to address this subject, because many Arabic language teachers in primary and secondary schools have poor digital skills. She aimed to address this subject because such skills are essential. For instance, in 2020, the Ministry of Education in Jordan decided to deliver distance education due to the Coronavirus crisis. Teachers -including Arabic language teachers- are obliged to face this crisis. The researcher aimed to address this subject because teachers -including Arabic language teachers- must have digital skills to handle challenges and do duties inside and outside classroom (Al-Nsairat, 2012)

For enabling teachers to handle challenges effectively, various teacher professional training courses are implemented. Such programs contribute to improving the teachers' teaching methods and implementing the vision of the Jordanian Ministry of Education. The latter vision aims at activating the role of Arabic language during the digital age. Such programs contribute to achieving comprehensive sustainable development and developing teachers' capabilities and digital skills. They contribute to expanding teachers' knowledge. Thus, they contribute to having a future generation who have much knowledge and excellent skills (Al-Sayed, 2011)

Due to having many rapid developments during the digital age, educators exert much effort to keep up with such developments. Such effort include: utilizing technologies in the learning environment. They including using technologies in setting long-term strategies. Increasing such use shall contribute to making reforms to the contemporary educational system (Al-Heelah, 2017).

According to Al-Anzi(2018) and Al-Sherari (2014), it is necessary to activate the use of modern technologies in education. It is necessary for principals and academic supervisors to monitor the way of using technologies in education. It's necessary to reduce the burden enforced on teachers for facilitating the use of modern technologies in education and the acquisition of digital skills by teachers. Administrator changes must be taken to facilitate such use and acquisition. Due to the significance of professional training courses, the researcher of the present study aimed to explore the effectiveness of professional training programs in developing the digital skills of Arabic language teachers from the perspective of principals and academic supervisors in the public schools in Zarqa

\section{The Study's Questions}

The researcher aimed to answer those questions

Q.1. What is the effectiveness of professional training programs in developing the digital skills of Arabic language teachers from the perspective of principals and academic supervisors in the public schools in Zarqa? 
Q.2. Is there any statistically significant difference -at the statistical significance level of $\alpha \geq 0.05$ - between the respondents' attitudes which can be attributed to job title, gender, experience or directorate?

\section{The Study's Significance:}

The present study is significant due to the following reasons:

1) Through the present study, the researcher recommends keeping up with the latest trends which aim at providing teachers with more attention and developing their digital skills. The development of teachers' digital skills shall enable teachers to keep up with the latest technological development. The latter skills can be developed through in-service teacher professional training programs.

2) The present study contributes to addressing some challenges that face Arabic language teachers.

3) The present study identifies some standards that must be met when setting plans for the teacher professional training programs.

4) The present study identifies the most important digital skills. That shall enable decision makers to design effective teacher professional training programs.

5) The present study enriches the Arab library and offers valuable results. It is considered the only study that identifies the relationship between the teacher professional training programs and teachers' digital skills of Arabic language teachers

\section{The Study's Limits}

The study's limits are listed below:

- Thematic limits: This study aimed to explore the effectiveness of professional training programs in developing the digital skills of Arabic language teachers. The targeted skills are: (elementary, intermediate, upper intermediate and advanced skills).

- Human limits: The researcher of the present study selects a sample that consists from principals and academic supervisors

- Spatial limits: The present study was conducted in the schools affiliated with (First Zarqa Directorate of Education, Second Zarqa Directorate of Education and Russeifa Directorate of Education)

- Temporal limits: The present study was conducted during the first semester of the academic year $(2020 / 2021)$

\section{Terminology:}

Professional training programs: They refer to the programs that are offered by the Jordanian Ministry of Education for developing the digital skills of Arabic language teachers. They are based on specific standards and aim at making effective changes to the educational process.

Digital skills: They refer to the skills of using technological devices, equipment and programs by Arabic language teachers for teaching students. They include: (elementary, intermediate, upper intermediate and advanced skills). They are assessed through a questionnaire from the perspective of principals and academic supervisors.

Arabic language teachers: They refer to the Arabic language teachers who work in public schools and hold BA degree in Arabic language. They must illustrate the content of Arabic language curricula. They engage in professional training programs to develop their skills- including their digital skills.

\section{Literature Review}

The professional training programs of Arabic language teachers have been receiving much attention by researchers in the Arab world in general and Jordan in particular. The same applies to the training needs of Arabic language teachers and the extent of employing ICTs by the latter teachers. In this regard, Al-Khashati (2019) aimed to explore the degree to which Arabic language teachers in Jordan possess the 21 st century skills from the perspective of principals and academic supervisors. He sampled 85 female and male principals and 12 female and male academic supervisors. He used a thirty-seven item questionnaire. This questionnaire sheds a light on (instructional skills, life skills and digital skills). It was found that the degree to which Arabic language teachers in Jordan possess the 21 st century skills is moderate. The mean of the digital skills is ranked last. The latter researcher recommends holding several training courses for Arabic language teachers to develop their digital skills. He recommends addressing such skills through the teacher guide.

Sa'adeh (2019) aimed to identify the training needs of secondary school Arabic language teachers in Al-Jam'a district in Amman. The sample consists from 58 female and male teachers. A forty-item questionnaire was used. It sheds a light on (planning, implementation, assessment and classroom management). The training needs of the targeted teachers is low. The mean of the assessment area is ranked first and the mean of implementation is ranked last. There is a significant difference between the respondents' attitudes which can be attributed to gender for the favor of males. There is a significant difference between the respondents' attitudes which can be attributed to experience for the favor of the ones with little experience. 
Al-Rwaili (2019) aimed to explore the degree to which the female educators benefit from the training programs provided by the Educational Center for Professional Development. He aimed to assess that in terms of (the teachers' self-awareness, active learning strategies, differentiated instruction, behavioural control skills and dialogue skills). He aimed to explore the applicability of the knowledge delivered through such programs to the targeted environment. The population consists from 247 educators. A simple random sample was selected. It consists from 95 educators. A questionnaire was used. The first part of the questionnaire collects demographic data about respondents. The second part of the questionnaire consists from 19 items. It aims to identify the degree to which the female educators benefit from the training programs. The third part consists from 12 items. It aims to provide suggestions for developing teachers. It was found that the degree to which the female educators benefitted from the training programs is high. Several suggestions were provided for developing teachers.

Al-Ardan (2017) aimed to explore the effectiveness of a training program in developing the IT skills of Arab language teachers in intermediate schools in Ha'el, KSA. The sample consists from 30 teachers. An observation checklist was used and an achievement test was administered. The validity and reliability of the instruments were measured. It was found that the concerned training program is very effective program in developing the IT skills of Arab language teachers in intermediate schools in Ha'el, KSA. The latter researcher recommends providing training courses for Arabic language teachers.

Al-Ja'afrah (2017) aimed to explore the degree to which Arabic language female and male teachers in secondary schools in Zarqa utilize technologies in instruction. The sample consists from 119 female and male teachers. The researcher used a forty five item questionnaire that sheds a light on 4 items. It was found that the degree to which Arabic language female and male teachers in secondary schools in Zarqa utilize technologies in instruction is moderate in all the areas jointly and separately. The mean of the implementation area is ranked first, followed by the planning, assessment and communication areas respectively. There aren't significant differences between the respondents' attitudes which can be attributed to gender or experience. The latter researcher recommends holding training courses for Arab language teachers to develop their abilities to utilize technologies in instruction.

Al-Faqeeh (2017)aimed to shed a light on the reality of the current professional development programs of public school Arabic language teachers in Saudi Arabia. He aimed to shed a light on the way of planning, implementing and assessing such programs. He aimed to develop a conceptual framework for the professional development of public school Arabic language teachers in Saudi Arabia. To meet the intended goals, the researcher analysed the content of several documents. He analysed the practices of teachers. He provided an effective conceptual framework for the professional development of public school Arabic language teachers in Saudi Arabia. He provided several recommendations for developing Arabic language professionally in accordance with the proposed framework.

Al-Azemi (2016) aimed to explore the reality of the training programs of the novice Arabic language teachers in Kuwait. He aimed to explore the relationship between such programs and professional development. He aimed to explore the respondents' attitudes in accordance with gender and school stage. The sample consists from 121 female and male novice Arabic language teachers in Kuwait who were recruited during (2015-2016). The latter researcher used two instruments. The first instrument consists from 44 items. It sheds a light on (the training needs, training methods, and cultural, academic and professional dimensions). The second instrument measures the extent of developing Arabic language novice teachers professionally. It consists from 29 items and sheds a light on 4 areas. It sheds a light on (the lesson planning, classroom management, instructional method and assessment). The validity and reliability of the instruments are measured. It was found that the effectiveness of the training programs of the novice Arabic language teachers in Kuwait is moderate. There isn't any significant difference between the respondents' attitudes which can be attributed to gender in all the areas jointly. However, there is such a difference in the professional dimension which is for the favor of females. There isn't any significant difference between the respondents' attitudes which can be attributed to school stage in all the areas jointly. However, there is such a difference in the academic dimension which is for the favor of primary school students. The extent of developing Arabic language novice teachers professionally is high.

Kathem and Abed Al-Kareem (2015) aimed to explore the training needs of female and male Arabic language teachers from their perspective. They aimed to explore the respondents' attitudes in accordance with gender, experience and academic qualification. The sample consists from 198 teachers (i.e. 94 teachers are males and 94 teachers are females). Those teachers were selected randomly. The latter researchers used a questionnaire that aims at exploring the training needs of the sampled teachers. The final version of the questionnaire consists from 47 items. It sheds a light on several areas (i.e. lesson planning, lesson delivery, teaching methods, and assessment methods). It was found that the level of the training needs of the training needs of female and male Arabic language teachers is high. It was found that there isn't any significant difference between the respondents' training needs which can be attributed to gender or years of experience. It was found that there are significant differences between the respondents' training needs which can be attributed to academic qualification.

Al-Khaldi (2012) aimed to explore the degree to which secondary school Arabic language teachers utilize technologies in instruction in accordance with total quality standards. He used a questionnaire and an observational 
checklist. Through using the questionnaire, data was collected from 300 female and male teachers. Through using an observational checklist, data was collected from 100 female and male checklist. The following results were concluded. For instance, the degree to which secondary school Arabic language teachers utilize technologies in instruction in accordance with total quality standards is moderate. The mean of the extent of using internet in instruction is ranked first followed by using audio devices and using computer respectively. Teachers rarely use animation in instruction. The extent of attention provided by teachers for improving the teaching-learning process is ranked first.

Some of the aforementioned studies -i.e. Al-Azemi (2016), Al-Faqeeh (2017) and Al- Rwaili (2019)- aimed to shed a light on the reality of professional development and training programs. Some of the aforementioned studies -e.g. Sa'adah (2019) and Kathem and Abed Al-Kareem (2015)- aimed to shed a light on the training needs of Arabic language teachers. Some of the aforementioned studies -e.g. Al- Ja'afrah (2017) and Al-Khaldi (2012) - aimed to shed a light on the extent of utilizing technologies in instruction by Arabic language teachers. Al-Khaldi (2012) concluded that the extent of utilizing technologies in instruction by Arabic language teachers is moderate. He recommends holding training courses for Arabic language teachers about the utilization of technologies. Reviewing the aforementioned studies enabled the researcher of the present study to determine the study's measures, develop the instrument and construct the theoretical framework of this study. Contrary to the aforementioned studies, the present study sheds a light on the effectiveness of professional training programs in developing the digital skills of Arabic language teachers from the perspective of principals and academic supervisors. Similar to the present study, Al-Khashati (2019) shed a light on the skills of Arabic language teachers in Jordan. For instance, he aimed to explore the degree to which Arabic language teachers in Jordan possess the 21 st century skills from the perspective of principals and academic supervisors. He recommends holding training courses to develop their digital skills. As far as the researcher knows, the present study is the first study that aimed to identify the on the effectiveness of professional training programs in developing the digital skills of Arabic language teachers from the perspective of principals and academic supervisors.

\section{Methodology}

\section{Population and Sample}

The study's population is represented in all the principals and academic supervisors who were working during the first semester of the academic year (2020/2021) in the (First Zarqa Directorate of Education, Second Zarqa Directorate of Education and Russeifa Directorate of Education).

A random stratified sampling method was used to select a sample from the public schools in Zarqa. The sample consists from 108 female and male principals and academic supervisors. Table (1) presents the distribution of the sample in accordance with several variables.

Table (1): The distribution of the sample in accordance with several variables

\begin{tabular}{|c|c|c|c|}
\hline Variable & Category & Frequency & Percentage \\
\hline \multirow[t]{3}{*}{ Gender } & Male & 50 & 56.5 \\
\hline & Female & 58 & 43.5 \\
\hline & Total & 108 & 100.0 \\
\hline \multirow[t]{3}{*}{ Job title } & Academic supervisors & 46 & 24.3 \\
\hline & Principals & 62 & 75.7 \\
\hline & Total & 108 & 100.0 \\
\hline \multirow[t]{4}{*}{ Experience } & Less than 5 years & 20 & 32.6 \\
\hline & $5-10$ years & 45 & 37.0 \\
\hline & More than 10 years & 34 & 30.4 \\
\hline & Total & 108 & 100.0 \\
\hline \multirow[t]{4}{*}{ Directorate } & First Zarqa Directorate of Education & 52 & 44.4 \\
\hline & Second Zarqa Directorate of Education & 20 & 20.2 \\
\hline & Russeifa Directorate of Education & 36 & 35.4 \\
\hline & Total & 108 & 100.0 \\
\hline
\end{tabular}

\section{The Study's Instrument}

To meet the study's goals, the researcher adopted a descriptive analytical approach. She developed a questionnaire based on the relevant literature. This questionnaire consists from two parts. The first part aims to collect demographic data about the respondents. The second part aims to assess the effectiveness of professional training programs in developing the digital skills of Arabic language teachers. The targeted skills are: (elementary, intermediate, upper intermediate and advanced skills). The initial version of the questionnaire consists from 41 items.

To measure the validity of the questionnaire, the initial version of the questionnaire was passed to faculty 
members who work in Jordanian public and private universities and academic supervisors. Those faculty members academic supervisors were asked to assess the questionnaire. In the light of their comments, changes were made to the questionnaire. The final version of the questionnaire consists from 41 items. The five point Likert scale was used. The Cronbach alpha coefficient values are calculated to measure the reliability of the questionnaire. The values are within the range of $0.81-0.87$. The overall Cronbach alpha coefficient value is 0.94 . It indicates that the questionnaire is reliable.

\section{Procedures:}

The researcher developed the questionnaire and distributed the questionnaire forms to the sample. She used the five point Likertscale that consists from five rating categories. Those categories are strongly agree, agree, neutral, disagree and strongly disagree. The scores of those categories are: 5, 4, 3, 2 and 1 respectively. The categories used for classifying means are shown below:

2.33 or less: Low

3.34- 3.66: Moderate

3.67 - 5: High

\section{Results and Discussion}

Results and discussion related to the first question:

Q.1. What is the effectiveness of professional training programs in developing the digital skills of Arabic language teachers from the perspective of principals and academic supervisors in the public schools in Zarqa?

To answer this question, means and standard deviations are calculated. Tables No. (2-6) present results related to question one:

Table (2): The means and standard deviations related to the effectiveness of professional training programs in developing the digital skills of Arabic language teachers from the perspective of principals and academic supervisors

\begin{tabular}{|l|l|l|l|l|}
\hline Rank & Area & Mean & Std. & Level \\
\hline 2 & Elementary skills & 3.71 & 0.59 & high \\
\hline 4 & Intermediate skills & 3.05 & 0.81 & Moderate \\
\hline 1 & Upper intermediate skills & 3.78 & 0.68 & High \\
\hline 3 & advanced skills & 3.07 & 0.78 & Moderate \\
\hline & Total & 3.44 & 0.64 & Moderate \\
\hline
\end{tabular}

Based on table (2), the means are within the range of (3.05-3.78). The overall mean is 3.44 . Thus, the effectiveness of professional training programs in developing the digital skills of Arabic language teachers is moderate from the perspective of principals and academic supervisors. That is because the Jordanian Ministry of Education started providing attention to the teacher professional training programs just few years ago. It's because the latter programs don't meet the required professional development standards much. It's because the latter ministry doesn't provide adequate attention to the professional training programs that aim at developing the digital skills of Arabic language skills. It's because the expertise of principals and academic supervisors aren't utilized as required in the latter programs. The means of two areas are high and the means of two areas are moderate. For instance, the means of the (upper intermediate skills) is 3.78 which is high. It indicates that teacher professional training programs provide much attention to the development of upper intermediate digital skills. The means of the (elementary skills) is 3.71 which is high and ranked second. The mean of (the advanced skills) is 3.07 which is moderate and ranked third. The mean of the (intermediate skills) is 3.05 which is moderate and ranked fourth. The means and standard deviations of the items of each area are presented below: 
Table (3): The means and standard deviations of the effectiveness of professional training programs in developing the digital elementary skills of Arabic language teachers

\begin{tabular}{|c|c|c|c|c|c|}
\hline No. & Rank & Area & Mean & Std. & Level \\
\hline \multicolumn{6}{|c|}{ Those programs can develop the Arabic language teachers' abilities in: } \\
\hline 1 & 2 & Turning on and turning off the ICT device & 4.00 & 1.26 & High \\
\hline 2 & 3 & The use of keyboard & 3.98 & 1.06 & High \\
\hline 3 & 6 & Creating an electronic file & 3.87 & 1.05 & High \\
\hline 4 & 4 & Activating the interactivity feature of the digital screen & 3.93 & 1.08 & High \\
\hline 5 & 5 & The use of Microsoft Office programs (i.e. Word „Excel PowerPoint( & 3.89 & 1.25 & High \\
\hline 6 & 7 & Searching for data through using search engines & 3.80 & 1.09 & High \\
\hline 7 & 1 & Creating an email account and activating it & 4.09 & 1.05 & High \\
\hline 8 & 8 & Creating accounts on social media platforms & 3.48 & 1.30 & Moderate \\
\hline 9 & 10 & Using blogs and Wikis & 3.04 & 1.28 & Moderate \\
\hline \multirow[t]{2}{*}{10} & 9 & Using e-learning systems (Google, Model, and Classroom) & 3.04 & 1.21 & Moderate \\
\hline & & Total & 3.71 & 0.59 & High \\
\hline
\end{tabular}

Based on table (3), the means are within the range of 4.09-3.04. The overall mean is 3.71. Thus, the effectiveness of professional training programs in developing the digital elementary skills of Arabic language teachers is high. Statement (7) states the following: (Those programs can develop the Arabic language teachers' abilities in: creating an email account and activating it). The mean of the latter statement is 4.09 which is high and ranked first. It means that professional training programs provide much attention to the use of emails. Statement (9) states the following: (Those programs can develop the Arabic language teachers' abilities in: Using blogs and Wikis). The mean of the latter statement is 3.04 which is moderate and ranked last. It indicates that professional training programs don't provide much attention to blogs and wikis. However, such attention must be provided to implement the vision of the Jordanian Ministry of Education. The latter vision aims at shifting the learning environment from a conventional one into a digital one in all educational institutions.

Table (4): The means and standard deviations of the effectiveness of professional training programs in developing the digital intermediate skills of Arabic language teachers

\begin{tabular}{|l|l|l|l|l|l|}
\hline No. & Rank & Area & \multicolumn{2}{l|}{ Mean } & \multicolumn{2}{l|}{ Std. } & Level \\
\hline \multicolumn{2}{|l|}{ Those programs can develop the Arabic language teachers' abilities in: } & 2.57 & 1.20 & Moderate \\
\hline 11 & 9 & Using electronic images in lessons & 2.65 & 1.20 & Moderate \\
\hline 12 & 6 & Using instruction YouTube videos for attracting students & 2.52 & 1.13 & Moderate \\
\hline 13 & 10 & Copying, pasting and sharing research-related links & 2.63 & 1.18 & Moderate \\
\hline 14 & 8 & Presenting, and editing an electronic instructional material & 2.41 & 1.17 & Moderate \\
\hline 15 & 11 & Presenting and editing audio clips during lessons & 2.65 & 1.20 & Moderate \\
\hline 16 & 7 & Making presentations & 3.78 & 1.09 & High \\
\hline 17 & 2 & Sending data to specific bodies & 3.61 & 1.14 & Moderate \\
\hline 18 & 4 & Creating plans and posting them on social media platforms & 3.78 & 1.21 & High \\
\hline 19 & 1 & Using info graphics to motivate students to learn & 3.70 & 1.11 & High \\
\hline 20 & 3 & Embedding e-activities in the lesson & 3.20 & 1.20 & Moderate \\
\hline 21 & 5 & $\begin{array}{l}\text { Using text messages and their associated features for communicating } \\
\text { with students }\end{array}$ & 3.05 & 0.81 & Moderate \\
\hline
\end{tabular}

Based on table (4), the means are within the range of 2.41-3.78. The overall mean is 3.05. Thus, the effectiveness of professional training programs in developing the digital intermediate skills of Arabic language teachers is moderate. Statement (19) states the following: (Those programs can develop the Arabic language teachers' abilities in: Using info graphics to motivate students to learn). The mean of the latter statement is 3.78 which is high and ranked first. Such attention is provided to info graphics due to their significance in Arabic language education. For instance, info graphics play a significant role in increasing students' retention and understanding for information and raising their students' achievement. Statement (15) states the following: (Those programs can develop the Arabic language teachers' abilities in presenting and editing audio clips during lessons). The mean of the latter statement is 2.41 which is moderate and ranked eleventh. However, those programs must provide more attention to the teachers' skills in using editing audio clips. That's because audio clips play a significant role in improving the quality of education. 
Table (5): The means and standard deviations of the effectiveness of professional training programs in developing the digital upper intermediate skills of Arabic language teachers

\begin{tabular}{|c|c|c|c|c|c|}
\hline No. & Rank & Area & Mean & Std. & Level \\
\hline \multicolumn{6}{|c|}{ Those programs can develop the Arabic language teachers' abilities in: } \\
\hline 22 & 7 & Using digital instruments for time management & 3.86 & 1.05 & high \\
\hline 23 & 3 & Designing and creating interactive audio clips and images & 3.92 & 1.08 & high \\
\hline 24 & 5 & $\begin{array}{l}\text { Using digital note taking methods for sharing academic material with } \\
\text { students }\end{array}$ & 3.88 & 1.25 & high \\
\hline 25 & 8 & Designing programs that include digital enrichment activities & 3.81 & 1.09 & high \\
\hline 26 & 1 & Creating various assessment methods, such as: e-exams & 4.09 & 1.05 & high \\
\hline 27 & 10 & Using digital feedback instruments & 3.48 & 1.30 & Moderate \\
\hline 28 & 11 & Taking screenshot for exchanging the academic material & 3.04 & 1.28 & Moderate \\
\hline 29 & 6 & Designing and using blogs to have dialogues with students & 3.87 & 1.05 & high \\
\hline 30 & 2 & Editing and adjusting interactive audio clips & 3.93 & 1.08 & high \\
\hline 31 & 4 & Running the online learning groups & 3.89 & 1.25 & high \\
\hline 32 & 9 & Using instructional interactive videos & 3.80 & 1.09 & high \\
\hline & & Total & 3.78 & 0.68 & high \\
\hline
\end{tabular}

Based on table (5), the means are within the range of 3.04-4.09. The overall mean is 3.78. Thus, the effectiveness of professional training programs in developing the digital upper intermediate skills of Arabic language teachers is high. Statement (26) states the following: (Those programs can develop the Arabic language teachers' abilities in: Creating various assessment methods, such as: e-exams). The mean of the latter statement is 4.09 which is high and ranked first. Such attention is provided to e-exams due to the significance of the assessment process. It is provided to e-exams for implementing the vision of the Jordanian Ministry of Education. The latter visions provides much attention to e-assessment, especially after shifting to distance education during the Coronavirus crisis. Statement (28) states the following: (Those programs can develop the Arabic language teachers' abilities in: Taking screenshot for exchanging the academic material ). The mean of the latter statement is 3.04 which is moderate and ranked eleventh. This means that more attention must be provided for improving the ability for enabling Arabic language teachers in exchanging the material with students effectively.

Table (6): The means and standard deviations of the effectiveness of professional training programs in developing the digital advanced skills of Arabic language teachers

\begin{tabular}{|l|l|l|l|l|l|}
\hline No. & Rank & Area & \multicolumn{2}{l|}{ Mean } & \multicolumn{2}{l|}{ Std. } & Level \\
\hline Those programs can develop the Arabic language teachers' abilities in: & 3.61 & 1.14 & Moderate \\
\hline 33 & 4 & Managing academic websites and activating their use & 3.78 & 1.21 & High \\
\hline 34 & 2 & Creating portfolio & 3.70 & 1.11 & High \\
\hline 35 & 3 & Designing and creating electronic charts and stickers & 3.80 & 1.13 & High \\
\hline 36 & 1 & Designing various electronic activities for students & 2.52 & 1.13 & Moderate \\
\hline 37 & 7 & Creating electronic platforms for students & 2.63 & 1.18 & Moderate \\
\hline 38 & 6 & Designing interactive academic games & 2.43 & 1.17 & Moderate \\
\hline 39 & 9 & Designing interactive e-books and sharing them & 2.65 & 1.20 & Moderate \\
\hline 40 & 5 & Detecting online threats (e.g. fraud and Malware) & 2.50 & 1.11 & Moderate \\
\hline 41 & 8 & Exercising and understanding digital copyright & 3.07 & 0.78 & Moderate \\
\hline & & Total &
\end{tabular}

Based on table (6), the means are within the range of 2.43- 3.80. The overall mean is 3.07. Thus, the effectiveness of professional training programs in developing the digital advanced skills of Arabic language teachers is moderate. Statement (36) states the following: (Those programs can develop the Arabic language teachers' abilities in: Designing various electronic activities for students). The mean of the latter statement is 3.80 which is high and ranked first. This indicates that those programs provide much attention to electronic activities. That is attributed to the significance of such activities. For instance, such activities play a significant role in improving students' academic achievement. Statement (39) states the following: (Those programs can develop the Arabic language teachers' abilities in: Designing interactive e-books and sharing them). The mean of the latter statement is 2.43 which is moderate and ranked ninth. That indicates that more awareness must be promoted about the role of Arabic language teachers in designing interactive e-books and sharing them. Designing interactive ebooks by those teachers shall enable them to exchange their ideas with experts and show creativity in teaching.

\section{Results related to the second question:}

Q.2. Is there any statistically significant difference -at the statistical significance level of $\alpha \geq 0.05$ - between the respondents' attitudes which can be attributed to job title, gender, experience or directorate?

To answer this question, means and standard deviation are calculated. T-test is conducted to explore whether the 
differences that may be attributed to job title or gender are statistically significant or not. Analysis of variance is conducted to explore whether the differences that may be attributed to experience and directorate are statistically significant or not. Tables No. (7-13) present the results related to the second question:

\section{First: Results related to job title}

Table (7): The results of the t-test to explore whether the differences that may be attributed to job title are statistically significant or not

\begin{tabular}{|c|c|c|c|c|c|c|c|c|}
\hline No. & Area & Job title & Frequency & Mean & Std. & T-value & Df. & Sig. \\
\hline \multirow[t]{2}{*}{1.} & \multirow[t]{2}{*}{ Elementary skills } & Academic supervisor & 46 & 3.49 & 0.60 & \multirow[t]{2}{*}{$1.620-$} & \multirow[t]{2}{*}{106} & \multirow[t]{2}{*}{0.11} \\
\hline & & Principal & 62 & 3.80 & 0.57 & & & \\
\hline \multirow[t]{2}{*}{2} & \multirow[t]{2}{*}{ Intermediate skills } & Academic supervisor & 46 & 2.64 & 0.82 & \multirow[t]{2}{*}{$2.214-$} & \multirow[t]{2}{*}{106} & \multirow[t]{2}{*}{0.03} \\
\hline & & Principal & 62 & 3.20 & 0.75 & & & \\
\hline \multirow[t]{2}{*}{3} & \multirow[t]{2}{*}{ Upper intermediate skills } & Academic supervisor & 46 & 3.53 & 0.73 & \multirow[t]{2}{*}{$1.603-$} & \multirow[t]{2}{*}{106} & \multirow[t]{2}{*}{0.11} \\
\hline & & Principal & 62 & 3.88 & 0.64 & & & \\
\hline \multirow[t]{2}{*}{4} & \multirow[t]{2}{*}{ Advanced skills } & Academic supervisor & 46 & 2.63 & 0.75 & \multirow[t]{2}{*}{$2.515-$} & \multirow[t]{2}{*}{106} & \multirow[t]{2}{*}{0.01} \\
\hline & & Principal & 62 & 3.24 & 0.74 & & & \\
\hline & \multirow[t]{2}{*}{ Total } & Academic supervisor & 46 & 3.12 & 0.65 & \multirow[t]{2}{*}{$2.213-$} & \multirow[t]{2}{*}{106} & \multirow[t]{2}{*}{0.03} \\
\hline & & Principal & 62 & 3.56 & 0.60 & & & \\
\hline
\end{tabular}

Based on table (7), the t-value of the intermediate skills is 2.214 ,. Thus, there is a statistically significant difference -at the statistical significance level of $\alpha \geq 0.05$ - between the respondents' attitudes in terms of the intermediate skills which can be attributed to job title. The latter difference is for the favour of principals. For instance, the mean of principals is 3.20 and the mean of academic supervisors is 2.64 in the latter area.

The $t$-value of the advanced skills is 2.515 . Thus, there is a statistically significant difference at the statistical significance level of $\alpha \geq 0.05$ - between the respondents' attitudes in terms of the advanced skills which can be attributed to job title. The latter difference is for the favour of principals. For instance, the mean of principals is 3.24 and the mean of academic supervisors is 2.63 in the latter area. There isn't any statistically significant difference -at the statistical significance level of $\alpha \geq 0.05$ - between the respondents' attitudes in terms of the elementary or upper intermediate skills which can be attributed to job title. That's because the t-values of the elementary and upper intermediate skills aren't statistically significant.

The overall t-value is 2.213 which is statistically significant. Thus, there is a statistically significant difference -at the statistical significance level of $\alpha \geq 0.05$ - between the respondents' attitudes in terms of the all the skills jointly which can be attributed to job title. The latter difference is for the favour of principals. For instance, the mean of principals is 3.56 and the mean of academic supervisors is 2.12 in all the areas jointly. The latter result indicate that principals and academic supervisors realize the significance of professional training programs in developing the Arabic language teachers' intermediate and advanced skills. It may be attributed to the fact that principals are more aware of the effectiveness of such programs due to their daily interaction with Arabic language teachers. However, the academic supervisors don't interact with teachers in a daily manner. Thus, they have less knowledge than principals about the effectiveness of such programs in developing the digital skills of Arabic language teachers.

Second: Results related to gender:

Table (8): The results of the t-test to explore whether the differences that may be attributed to gender are statistically significant or not

\begin{tabular}{|c|c|c|c|c|c|c|c|c|}
\hline No. & Area & Job title & Frequency & Mean & Std. & T-value & Df. & Sig. \\
\hline \multirow[t]{2}{*}{1.} & \multirow[t]{2}{*}{ Elementary skills } & Male & 3.63 & 0.56 & 0.60 & \multirow[t]{2}{*}{$1.079-$} & \multirow[t]{2}{*}{106} & \multirow[t]{2}{*}{0.28} \\
\hline & & Female & 3.82 & 0.62 & 0.57 & & & \\
\hline \multirow[t]{2}{*}{2} & \multirow[t]{2}{*}{ Intermediate skills } & Male & 2.88 & 0.71 & 0.82 & \multirow[t]{2}{*}{$1.604-$} & \multirow[t]{2}{*}{106} & \multirow[t]{2}{*}{0.116} \\
\hline & & Female & 3.26 & 0.88 & 0.75 & & & \\
\hline \multirow[t]{2}{*}{3} & \multirow[t]{2}{*}{ Upper intermediate skills } & Male & 3.66 & 0.65 & 0.73 & \multirow[t]{2}{*}{$1.40-$} & \multirow[t]{2}{*}{106} & \multirow[t]{2}{*}{0.168} \\
\hline & & Female & 3.94 & 0.69 & 0.64 & & & \\
\hline \multirow[t]{2}{*}{4} & \multirow[t]{2}{*}{ Advanced skills } & Male & 2.89 & 0.68 & 0.75 & \multirow[t]{2}{*}{$1.78-$} & \multirow[t]{2}{*}{106} & \multirow[t]{2}{*}{0.081} \\
\hline & & Female & 3.30 & 0.86 & 0.74 & & & \\
\hline & \multirow[t]{2}{*}{ Total } & Male & 3.30 & 0.57 & 0.65 & \multirow[t]{2}{*}{$1.64-$} & \multirow[t]{2}{*}{106} & \multirow[t]{2}{*}{0.107} \\
\hline & & Female & 3.61 & 0.70 & 0.60 & & & \\
\hline
\end{tabular}

Based on table (8), the t-value is 0.164 . Thus, there isn't any statistically significant difference -at the statistical significance level of $\alpha \geq 0.05$ - between the respondents' attitudes in terms of the all the skills jointly and separately which can be attributed to gender. The latter result indicate that female and male have similar attitudes towards the effectiveness of such programs in developing the (elementary, intermediate, upper intermediate and advanced digital skills) of Arabic langauge skills. It is consistent with the result concluded by Sa'adeh (2019), AlJa'afrah (2017), and Al-Azemi (2016). 
Third: Results related to experience

Table (9): Means and standard deviations to explore the respondents' attitudes in accordance with experience

\begin{tabular}{|c|c|c|c|c|}
\hline No. & Area & Experience & Mean & Std. \\
\hline \multirow[t]{4}{*}{1} & \multirow{4}{*}{$\begin{array}{l}\text { Elementary } \\
\text { skills }\end{array}$} & Less than 5 years & 3.55 & 0.60 \\
\hline & & $5-10$ years & 3.91 & 0.59 \\
\hline & & More than 10 years & 3.66 & 0.55 \\
\hline & & Total & 3.71 & 0.59 \\
\hline \multirow[t]{4}{*}{2} & \multirow{4}{*}{$\begin{array}{l}\text { intermediate } \\
\text { skills }\end{array}$} & Less than 5 years & 2.60 & 0.72 \\
\hline & & $5-10$ years & 3.36 & 0.83 \\
\hline & & More than 10 years & 3.14 & 0.68 \\
\hline & & Total & 3.05 & 0.81 \\
\hline \multirow[t]{4}{*}{3} & \multirow{4}{*}{$\begin{array}{l}\text { Upper } \\
\text { intermediate } \\
\text { skills }\end{array}$} & Less than 5 years & 3.68 & 0.76 \\
\hline & & $5-10$ years & 3.94 & 0.63 \\
\hline & & More than 10 years & 3.55 & 0.60 \\
\hline & & Total & 3.91 & 0.59 \\
\hline \multirow[t]{8}{*}{4} & \multirow[t]{4}{*}{ Advanced skills } & Less than 5 years & 3.66 & 0.55 \\
\hline & & $5-10$ years & 3.71 & 0.59 \\
\hline & & More than 10 years & 2.60 & 0.72 \\
\hline & & Total & 3.36 & 0.83 \\
\hline & \multirow[t]{4}{*}{ Total } & Less than 5 years & 3.14 & 0.68 \\
\hline & & $5-10$ years & 3.05 & 0.81 \\
\hline & & More than 10 years & 3.68 & 0.76 \\
\hline & & Total & 3.94 & 0.63 \\
\hline
\end{tabular}

Based on table (9), it appears that there are differences between the respondents' attitudes which can be attributed to experience. To explore whether those differences are statistically significant or not, the one way analysis of variance (ANOVA) is conducted. The results of the latter analysis are presented in table (10) below:

Table (10): The results of one way analysis of variance (ANOVA) to explore whether the differences that may be attributed to experience are statistically significant or not

\begin{tabular}{|c|c|c|c|c|c|c|c|}
\hline No. & Area & Source of variance & Sum of squares & Df. & Mean square & f value & Sig. \\
\hline \multirow[t]{3}{*}{1} & \multirow[t]{3}{*}{ Elementary skills } & Between groups & 1.091 & 3 & 0.546 & \multirow{3}{*}{1.607} & \multirow{3}{*}{0.212} \\
\hline & & Within groups & 14.601 & 104 & 0.340 & & \\
\hline & & Total & 15.692 & 107 & & & \\
\hline \multirow[t]{3}{*}{2} & \multirow[t]{3}{*}{ Intermediate skills } & Between groups & 4.773 & 3 & 2.386 & \multirow{3}{*}{4.198} & \multirow{3}{*}{0.022} \\
\hline & & Within groups & 24.446 & 104 & 0.569 & & \\
\hline & & Total & 29.219 & 107 & & & \\
\hline \multirow[t]{3}{*}{3} & \multirow[t]{3}{*}{ Upper intermediate skills } & Between groups & 0.682 & 3 & 0.341 & \multirow{3}{*}{0.732} & \multirow{3}{*}{0.487} \\
\hline & & Within groups & 20.020 & 104 & 466. & & \\
\hline & & Total & 20.702 & 107 & & & \\
\hline \multirow[t]{3}{*}{4} & \multirow[t]{3}{*}{ Advanced skills } & Between groups & 3.956 & 3 & 1.978 & \multirow{3}{*}{3.595} & \multirow{3}{*}{0.036} \\
\hline & & Within groups & 23.658 & 104 & 0.550 & & \\
\hline & & Total & 27.614 & 107 & & & \\
\hline & \multirow[t]{3}{*}{ Total } & Between groups & 2.147 & 3 & 1.074 & \multirow{3}{*}{2.823} & \multirow{3}{*}{0.071} \\
\hline & & Within groups & 16.356 & 104 & 0.380 & & \\
\hline & & Total & 18.503 & 107 & & & \\
\hline
\end{tabular}

Based on table (10), there isn't any statistically significant difference -at the statistical significance level of $\alpha \geq 0.05$ - between the respondents' attitudes in terms of primary and upper intermediate skills which can be attributed to experience. In addition, there isn't any statistically significant difference between the respondents' attitudes in terms of all the areas jointly which can be attributed to experience.

There are statistically significant differences -at the statistical significance level of $\alpha \geq 0.05$ - between the respondents' attitudes in terms of advanced and intermediate skills which can be attributed to experience. To explore the ones whose the differences are for their favour, Scheffe test was conducted. Table (11) presents the results of Scheffe test in this regard. 
Table (11): The results of Scheffe test for exploring the ones whose the experience-related differences are for their favor in terms of primary and upper intermediate skills

\begin{tabular}{|c|l|l|l|l|l|}
\hline \multicolumn{1}{|c|}{ Area } & Expereince & Mean & Less than 5 years & 5-10 years & More than 10 years \\
\hline \multirow{4}{*}{ Intermediate skills } & Less than 5 years & 2.60 & $=$ & $*_{-}-76$ & $*_{-}-0.54$ \\
\cline { 2 - 6 } & 5-10 years & 3.36 & & $=$ & 0.22 \\
\cline { 2 - 6 } & More than 10 years & 3.14 & & & $=$ \\
\hline \multirow{2}{*}{ Advanced skills } & Less than 5 years & 3.66 & $=$ & 0.05 & $* 1.06$ \\
\cline { 2 - 6 } & 5-10 years & 3.71 & & $=$ & $* 1.11$ \\
\cline { 2 - 6 } & More than 10 years & 2.60 & & \multicolumn{2}{|c}{} \\
\hline
\end{tabular}

Based on table (11), there are statistically significant differences -at the statistical significance level of $\alpha$ $\geq 0.05$ - between the respondents' attitudes in terms of intermediate skills which can be attributed to experience. The latter differences are for the favour of the ones who have 5-10 years $(\mathrm{m}=3.36)$ and the ones who have more than 10 years $(\mathrm{m}=3.14)$. That's concluded when conducting a comparison between the ones have less than 5 years from one hand and the ones who have 5-10 years and the ones who have more than 10 years from another hand.

There are statistically significant differences -at the statistical significance level of $\alpha \geq 0.05$ - between the respondents' attitudes in terms of advanced skills which can be attributed to experience. The latter differences are for the favour of the ones who have less than 5 year $(\mathrm{m}=3.66)$ and the ones who have $(5-10)$ years $(\mathrm{m}=3.71)$. That's concluded when conducting a comparison between the ones have less than 5 year and the ones who have (5-10) years from one hand and the ones who have more than 10 years from another hand. The latter results indicate that experienceaffects the respondents' attitudes.

\section{Fourth: Results related to directorate}

Table (12): The results of the t-test to explore whether the differences that may be attributed to directorate are statistically significant or not

\begin{tabular}{|l|l|l|l|l|}
\hline Area & Directorate & Frequency & Mean & Std. \\
\hline Elementary skills & First Zarqa Directorate of Education & 52 & 3.73 & 0.61 \\
\cline { 2 - 5 } & Second Zarqa Directorate of Education & 20 & 3.61 & 0.81 \\
\cline { 2 - 5 } & Russeifa Directorate of Educatio & 36 & 3.73 & 0.35 \\
\cline { 2 - 5 } & Total & 108 & 3.69 & 0.59 \\
\hline \multirow{5}{*}{ Intermediate skills } & First Zarqa Directorate of Education & 52 & 2.90 & 0.84 \\
\cline { 2 - 5 } & Second Zarqa Directorate of Education & 20 & 3.24 & 0.93 \\
\cline { 2 - 5 } & Russeifa Directorate of Educatio & 36 & 2.95 & 0.76 \\
\cline { 2 - 5 } & Total & 108 & 3.03 & 0.82 \\
\hline \multirow{5}{*}{ Advper intermediate skills } & First Zarqa Directorate of Education & 52 & 3.77 & 0.76 \\
\cline { 2 - 5 } & Second Zarqa Directorate of Education & 20 & 3.72 & 0.74 \\
\cline { 2 - 5 } & Russeifa Directorate of Educatio & 36 & 3.94 & 0.54 \\
\cline { 2 - 5 } & Total & 108 & 3.81 & 0.68 \\
\hline \multirow{5}{*}{ Total } & First Zarqa Directorate of Education & 52 & 2.97 & 0.86 \\
\cline { 2 - 5 } & Second Zarqa Directorate of Education & 20 & 3.29 & 0.89 \\
\cline { 2 - 5 } & Russeifa Directorate of Educatio & 36 & 2.89 & 0.69 \\
\cline { 2 - 5 } & Total & 108 & 3.05 & 0.81 \\
\hline & First Zarqa Directorate of Education & 52 & 3.39 & 0.70 \\
\cline { 2 - 5 } & Second Zarqa Directorate of Education & 20 & 3.47 & 0.83 \\
\cline { 2 - 5 } & Russeifa Directorate of Educatio & 36 & 3.43 & 0.49 \\
\cline { 2 - 5 } & Total & 108 & 3.43 & 0.67 \\
\hline
\end{tabular}

Based on table (12), it appears that there are statistically significant differences between the respondents' attitudes which can be attributed to directorate in all the areas jointly and separately. To explore the ones whose the differences are for their favour, the one way analysis of variance (ANOVA) is conducted. Table (13) presents the results of the latter analysis. 
Table (13): The results of the one way analysis of variance (ANOVA) to explore whether the differences that can be attributed to directorate are statistically significant or not

\begin{tabular}{|c|c|c|c|c|c|c|c|}
\hline No. & Area & Source of variance & Sum of squares & Df. & Mean square & f value & Sig. \\
\hline \multirow[t]{3}{*}{1} & \multirow[t]{3}{*}{ Elementary skills } & Between groups & 0.106 & 3 & 0.035 & \multirow{3}{*}{0.095} & \multirow{3}{*}{0.962} \\
\hline & & Within groups & 15.586 & 104 & 0.371 & & \\
\hline & & Total & 15.692 & 107 & & & \\
\hline \multirow[t]{3}{*}{2} & \multirow[t]{3}{*}{ Intermediate skills } & Between groups & 1.597 & 3 & 0.532 & \multirow{3}{*}{0.809} & \multirow{3}{*}{0.496} \\
\hline & & Within groups & 27.622 & 104 & 0.658 & & \\
\hline & & Total & 29.219 & 107 & & & \\
\hline \multirow[t]{3}{*}{3} & \multirow[t]{3}{*}{ Upper intermediate skills } & Between groups & 0.215 & 3 & 0.072 & \multirow{3}{*}{0.147} & \multirow{3}{*}{0.931} \\
\hline & & Within groups & 20.487 & 104 & 0.488 & & \\
\hline & & Total & 20.702 & 107 & & & \\
\hline \multirow[t]{3}{*}{4} & \multirow[t]{3}{*}{ Advanced skills } & Between groups & 1.241 & 3 & 0.414 & \multirow{3}{*}{0.659} & \multirow{3}{*}{0.582} \\
\hline & & Within groups & 26.373 & 104 & 628. & & \\
\hline & & Total & 27.614 & 107 & & & \\
\hline & \multirow[t]{3}{*}{ Total } & Between groups & 0.153 & 3 & 0.051 & \multirow{3}{*}{0.117} & \multirow{3}{*}{0.950} \\
\hline & & Within groups & 18.350 & 104 & 0.437 & & \\
\hline & & Total & 18.503 & 107 & & & \\
\hline
\end{tabular}

Based on table (13), there isn't any statistically significant difference - at the statistical significance level of $\alpha \geq 0.05$ - between the respondents' attitudes which can be attributed to directorate in all the areas jointly and separately. The latter result may be attributed to the fact that the teacher professional training programs target teachers in all directorates rather than teachers in a specific directorate only.

\section{Recommendations:}

The researcher recommends:

1. Designing effective professional training programs in the aim of developing the digital skills of Arabic langauge teachers.

2. Employing the professional training programs that are designed by institutions in other Arab countries and aim at developing teachers' digital skills and providing attention to Arabic language.

3. Making changes to the Arabic language teacher guides in a manner that contributes to improving the digital skills of those teachers

4. Conducting studies about the digital skills of other teachers (e.g. English langauge teachers, social studies teachers and etc.)

\section{References}

1. Al- Soroor, Norah Hadi (2018). Employing modern technologies in the educational process in Saudi Arabia and its role in improving the performance of teachers and students. The Journal of Educational and Psychological Sciences. 18(4).

2. Al- Ja'afrah, Abed Al-Sallam (2017). The extent of employing technologies in education by Arabic langauge teachers in secondary schools from their perspective. Journal of the Association of Arab Universities for Research in Higher Education.37(3)

3. Al-Harahsheh, Mohammad Abboud (2010). The teacher development in the light of the contemporary global challenges. A worksheet submitted to a conference titled (The future of the teacher development in the faculties of education). Helwan University. Egypt

4. Al-Harbi, Abdullah (2016). Practical steps for online teaching and learning.Amman. Jordan, Dar AlMaseerah

5. Al-Heelah, Mohammad Mahmood (2017). Educational technology between theory and application. 14 ${ }^{\text {th }}$ edition. Amman. Jordan, Dar Al-Maseerah

6. Al-Khaldi, Fathmeh Mousa (2012). The extent of employing technologies by Arabic langauge teachers in secondary schools in accordance with total quality standards. Unpublished MA thesis. The Islamic University. Gaza, Palestine

7. Al-Khashati, Ali Khalaf Hassan (2019). The degree to which Arabic langauge teachers in Jordan possess the $21^{\text {st }}$ century skills from the perspective of principals and academic supervisors. Unpublished MA thesis. Al Al-Bait University. Mafraq. Jordan

8. Al- Rwaili, Samah (2019). The role of the training programs provided by the Educational Center for Professional Development in developing the female educators professionally. The International Interdisciplinary Journal of Education (IIJE). 11(8), p.66-81

9. Sa'adeh, Fayzeh (2019). The training needs of Arabic langauge female and male teachers in the secondary 
schools affiliated with the Directorate of Education of Al-Jam'ah District.The Islamic University Journal for Studies in Educational and Psychology Sciences. 27(1).

10. Al-Sayed, Yaser (2011). A teacher development program and its impact on the quality of education. The Journal of Educational Sciences -the faculty of Education at Omdurman Islamic University (OIU). Sudan

11. Al- Sherari, Ayed Hamdan Sulaiman (2014). The degree to which social studies teachers in secondary schools utilize modern technologies and the associated challenges in Al-Jawf. Unpublished MA thesis. Yarmouk University. Jordan

12. Al-Azemi, Mefleh Mubarah (2016). The training programs of new Arabic language teachers in Kuwait and their relationship with professional development. Unpublished MA thesis. The faculty of Educational Sciences. Al Al-Bait University. Mafraq. Jordan

13. Al-Ardan, Sultan bin Abdullah (2017). The effectiveness of a training program in developing the IT skills of Arab language teachers in intermediate schools in Ha'el. The International Interdisciplinary Journal of Education (IIJE). 6(5).

14. Al-Anzi, Talal Marwan Khalaf (2018). The extent of utilizing educational technologies in Islamic education course in intermediate schools from the teachers' perspective in Kuwait.. Unpublished MA thesis. Al-Bait University. Mafraq. Jordan

15. Al-Faqeeh, Ahmad Hassan (2017). A proposed conceptual framework for developing Arabic language teachers professionally in public schools in Saudi Arabia. Risalat Ul-Khaleej Al-Arabi Journal. 38(146).

16. Kathem, Iqbal and Abed Al-Kareem, Asma' (2015). The training needs of Arabic language female and male teachers from their perspective.Journal of Adab Al-Kufah. 21(1).

17.Al-Mallah, Tamer (2019). Technological development of teachers: sustainability and professionalismhttps://www.new-educ.com/

18. Al- Nsairat, Saleh (2012). Professional development of Arabic language teachers and the development of their capabilities: A new shift in the light of the standard-based education. Al-Husson University. Abu Dhabi

19. Corcoran, Thomas (1995): Helping teachers teach well transforming professional development, A guide for state policymakers, national governors Association, Washington, D.C.

20. Davies, lan(1991): A defense of Quality; full time Initial teacher training courses. Journal of further and higher education, $15:(1), \mathrm{p} 21-25$.

21. Guskey, Thomas (2000): Evaluating professional development, Corwin press, Inc., California. 